\title{
Understanding the Exhibitionary Characteristics of Popular Music Museums.
}

\author{
Charles Fairchild*
}

\begin{abstract}
:
The literature on the popular music museum has primarily focused on the study of heritage and cultural memory with a secondary focus on tourism. Given the unprecedented expansion of the museum sector worldwide in recent decades, which has produced an increasing number of major museums dedicated to popular music, it is an opportune time to expand this range of analytical concerns. Specifically, the development of popular music museums has not yet been closely examined within the broader historical trajectory of the so-called 'new museum.' This article seeks to outline the range of exhibitionary types commonly used in a range of high-profile popular music museums in pursuit of this line of inquiry. The goal is not simply to produce a generic survey or typology of displays, but to place the use of different forms of museum display within the specific historical trajectory that has produced steadily larger numbers of these kinds of museums in recent years. I organize these exhibitionary types into two broad streams of museum exhibition practice implied in the historical survey presented here: a populist-vernacular stream of museum display and an institutional-educational one. I seek to place the exhibitionary practices of contemporary popular music museums in a broader and longer trajectory of similar practices in order to get a more grounded sense of the more important characteristics of these kinds of museums.
\end{abstract}

Key words: popular music; museum history; music industry; cultural intermediaries.

\section{Introduction}

The formal commemoration of popular music in dedicated museums, individual exhibitions, halls of fame, historic houses, or related types of institutions is a long-standing and common practice. While large numbers of such places are found in the southern United States, many similar institutions exist in cities such as Los Angeles, New York, Chicago, Seattle, Cleveland, and Liverpool (UK), and increasingly around the world in such places as Australia, Denmark, Sweden, and Jamaica (Mortensen and Madsen, 2015; Baker et. al., 2016a). Most scholarly work on the subject has approached the topic through the lenses of heritage, cultural memory, and tourism (Cohen, et. al. 2015; Roberts and Cohen, 2014; Brandellero and Janssen, 2014; Bennett, 2009; Bennett and Rogers, 2016; Leonard, 2010; Leonard, 2007; Gibson and Connell, 2007; Cohen, 2007). There have also been general works on the relationship between museums and popular culture and essays analyzing specific one-off exhibitions, usually in more generalist institutions (Moore, 1997; Brabazon and Mallinder, 2006; Reising, 2001; Forman, 2002; Suisman, 2000; Bergengren, 1999; Moore, 1995; Kalata et. al., 1997). The central concern for most of this work has been to gauge the extent to which an adequate representation of a presumed collective musical past is possible in a museum. As such, many of the distinct and specific exhibitionary characteristics of popular music museums have not been closely examined, especially as they relate to the longer and more general history of museum display. 
This article seeks to identify and examine common display strategies in high-profile popular music museums. I will analyze four exhibits, one each from the Country Music Hall of Fame and Museum in Nashville, Tennessee; the Memphis Rock and Soul Museum in Memphis, Tennessee; the Experience Music Project in Seattle, Washington; and the Beatles' Story in Liverpool. Each exhibit draws implicitly on a long history of visual display techniques developed by art museums, social history museums, historical reconstructions, wax museums, and other sites. All of the institutions that have helped shape contemporary popular music museums are part of what Kylie Message calls a "chronology that emerged in the mid-nineteenth century with the emergence of new technologies and strategies of spectacle, experience, conspicuous consumption and novelty' (Message, 2006: 605).

Popular music museums are markedly ecumenical in the many different types of visual display they have embraced. They use a potpourri of methods, techniques, and strategies that have their origins in a broad array of institutional types and exhibitionary styles. One helpful way to organize and understand the broad range of display techniques these museums use is to examine them in relation to two broad streams of museum practice suggested in historical surveys. I will call them a populist-vernacular stream and an institutional-educational one. The former includes the rich history of the display of commodities in department stores and popular entertainments such as dramatic panoramas and wax museums as well as world's fairs and expositions (Greenhalgh, 1989; Sandberg, 2003; Colligan, 2002; Crary, 2002; Rydell, 2006; Mitchell, 2004). The latter includes more formal, institutional types of display from history museums, natural history museums, and ethnological or ethnographic displays (Bennett, 1995; Bennett, 2006; Griffiths, 2002; Henning, 2006; Kirshenblatt-Gimblett, 2006). Further, popular music museums also draw on corporate museums, halls of fame, personal or private museums, as well as shrines and pilgrimage sites. As Preziosi and Farago note, 'we live in a world in which virtually anything may be exhibited in a museum, and in which virtually anything can be made to function as a museum' (Preziosi and Farago, 2004:2). The contemporary popular music museum is therefore notable for its reliance on forms of exhibition and display from across a broad spectrum of institutions.

The diverse acts of exhibition and display found in these museums share at least four characteristics. Foremost among them are the ways in which staff ascribe particular forms of value and legitimacy to items on display. Specifically, sounds, images, and objects that can be said to represent a collective musical past are particularly valued. This in turn demands a broadly construed validation and justification for the shape and tenor of the exhibitions which, extensively deploy the mythic origins of 'the music.' Second, this collective past places museum visitors within larger communal social formations; exhibits are founded on the implicit assumption that visitors arrive at the museum already armed with some sense of their own shared experience of the musical heritage on display. This sense of communality makes the wider experience of these exhibits coherent and meaningful. Third, these museums have a pronounced tendency towards familiar, traditional, and safe forms of museum practice with displays and music that are presented as accurate representations of a wider musical world that precedes their appearance in an exhibit. The inevitable conflicts and dissenting perspectives readily apparent in the history of popular music are minimized with the construction of a common audience; thus, the fourth characteristic is a broad flattening of racial and social divisions. The specific ways in which these institutions do this are instructive to examine.

\section{Exhibitionary Characteristics of Four Popular Music Museum Exhibits}

One of the primary ways in which popular music museums display the value and legitimacy of their collections through particular modes of exhibition is drawn from the institutional-educational stream of art museums and natural and social history museums. Several qualities shared by art museums and popular music museums illustrate this point. Art museums display exemplary works of demonstrable historical importance and pieces regarded as worthy of imitation. These institutions enhance the reputation of artists by cultivating their works with an aura of material and conceptual uniqueness (Henning, 2006:16-7). The canonization of exemplary works is generally organized by medium and historical period as well as through the thematic juxtaposition of various works and artists. These display techniques exist in an implicit and 
intertwined relationship with mediating critical discourses in art criticism and art history.

Popular music museums have drawn on these characteristics of art museums to shape how they canonize artists and they organize their works. We are meant to see and hear extraordinary works produced by extraordinary artists usually organized in a narrative or historical sequence centered on the musical traditions or genres to which artists contributed. More often than not, popular music museums have done so under the presumption that their organizational schemas loyally reflect 'the societies within which they are located, faithfully replicating or reconstructing social or cultural histories that at the same time are presumed to pre-exist their re-presentation' (Preziosi and Farago, 2012: 143). This fact has a few important implications. First, it presumes an ideal spectator or listener who is already part of the social formation the museum is purporting to reflect, a formation that is also meant to encompass the music. Second, it suggests that these institutions are somehow not 'representational artifacts' in their own right and are neither distinct nor separate from their contents (Preziosi and Farago, 2012: 142). These institutions often try to appear as if they are neutral arbiters of the value of the materials they have carefully collected and displayed or music that has been recorded and played. They can only do this if their exhibits suggest that the value of the collections already resides elsewhere (Preziosi and Farago, 2012:142). In other words, these museums implicitly claim to be invoking an inevitable connection between the value and relevance of the materials they exhibit and the past, a collective past which subsumes the artists, their art, and their publics into a collective experience that is just 'out there,' somewhere. One important way they do this is by attempting to link their displays and exhibits to the deepest wellsprings of 'the music,' or its origins.

One exhibit illustrates these points particularly well. At the end of the main exhibition hall on the second floor of the Country Music Hall of Fame and Museum in Nashville, Tennessee, there is a 'shrine' to the ancestors and forebears of country music. It is called the Hall of Fame Rotunda. In this room, the commemorative plaque for each inductee is permanently displayed. This room is part of a larger set of symbolic architectural gestures produced by this museum that are meant to ensconce visitors physically in the history of country music. As such, its symbolic and practical importance are intertwined. According to the museum's Visitor's Companion, the rotunda is meant to variously resemble 'a drum kit, a rural water tower, or a grain silo' (Country Music Hall..., 2004:5). It is capped by a tower that is a replica of the distinctive diamond-shaped tower, of WSM radio station, broadcaster of the Grand Ole Opry. It is also intended to recall a church spire, since religion has served as a central influence on this musical tradition. As the tower pierces the roof of the rotunda, it penetrates a stack of circles meant to 'evoke the evolution of recording media, from the 78-rpm record to the vinyl long-playing album, the 45-rpm single, and the compact disc' (ibid.). The final adornments on the exterior of the rotunda are a collection of stone bars ringing the entire circumference. Set on five bar lines carved into the concrete base, they match the melody to the Carter Family's version of 'Can the Circle Be Unbroken?', long said to have 'started' the country music industry upon its release in 1935 (ibid.).

Material symbolism abounds inside the rotunda as well. A light reddish brown sandstone called Crab Orchard stone, quarried from Eastern Tennessee, adorns the walls which hold the plaques of the Hall of Fame members. The room is an open, quiet, contemplative space dedicated to acknowledging the presumed permanence of this musical tradition. The mottled brown and red flooring is made from southern pine, 'like that used in the floors of southern warehouses and factories' (ibid.). According to Dolly Parton, the narrator of the audio guide for this final stop on the museum's guided tour, 'this special room was designed to recognize hall of fame members in a style that's in keeping with the high honor. Everyone who is recognized here is an equal. The members' plaques are placed randomly around the room' and 'the room is round to ensure that every hall of fame member has a place of equal importance.' At the center of the room and, to some extent, at the symbolic heart of what the museum calls 'the pinnacle of country music,' is a sandstone disc (Country Music Hall..., 2004:54). This disc was originally installed at the entranceway to first Country Music Hall of Fame and Museum in 1967, which was located on $16^{\text {th }}$ Avenue in the heart of Nashville's famous Music Row. It was moved to this new home in 2001. It reads: 'Here lives country music: Its spirit, its soul and its history, its people and its songs.' Directly above it rests the bottom half of the rotunda's 
tower, dramatically descending from the roof coming to a sharp point to loom about fifteen feet from the floor. Just below a row of windows at the top of the space is a thick band of a deep maroon with the words 'Will the Circle be Unbroken' stretching across half the diameter of the room in massive gold letters. ${ }^{1}$ This series of highly stylized design gestures are intended to give spectators the impression that they are part of something much bigger than themselves.

One of the most striking aspects of this room is the presence of Thomas Hart Benton's painting called 'The Sources of Country Music.' This painting was the last canvas ever produced by Benton. His later art was comprised of dramatic and stark representational works largely depicting 'Americana and the simple, rural small town life' (Country Music Hall Hall of Fame and Museum, 2004:58). Building on Benton's continuing desire to produce paintings that 'would carry unmistakably American meanings for Americans and for as many of them as possible,' this particular work is described in the Visitor's Guide an exemplar of Benton's 'notions of democratic art and its accessibility to the common man' (Country Music Hall of Fame and Museum, 2004:59). As such, it is a material manifestation of the purpose of the rotunda itself. The six by ten foot painting hangs in the center of the back wall of the rotunda, facing visitors as they enter. The composition is organized around a series of figures, each representing an element constituting country music. In the upper left corner in the rear, we see a small group of women each wearing a bonnet dressed in their 'Sunday best' singing from hymnals as their preacher guides their performance. Separated from them by a low wooden wall are two seated men playing fiddles, together with two women, one playing a dulcimer on her lap, the other standing and singing. They play together on a simple wooden floor as several couples dance behind them. In the right foreground, a cowboy stands playing his guitar while slightly to his left and further in the background an African-American banjo player mimics his pose. In the far background, we see a church on a hill glowing in reflected morning light, while a group of African-American women dance on the riverside below as a steamboat passes by. The painting is dotted with objects that are vividly resonant within the history of country music, such as a jug, a coil of rope, and a saddle.

The most dynamic element of the painting is an early twentieth-century passenger train, its body lurching forward as it roars through the middle background. The eyes of the musicians and dancers are locked on it as if their music is accompanying the inevitable march of progress it symbolizes. All of the elements of the painting tilt dynamically towards the center of the canvas as the collective gaze of the main figures takes our eyes upwards towards the train that unifies this visually crowded and diverse scene. Benton used 'as his model Engine No. 382, the "Cannonball Express," the train in which Casey Jones perished in his famous wreck.'2 This painting becomes an expression of the museum's aims, linking diverse and complex social histories and situating them within a unified and harmonious landscape of American musical history. The canvas does so through the judicious use of fact and fancy, the verifiable and the mythological. The social histories of American popular music are deeply inflected with often brutal histories of racial, gender, and economic oppression are elided and obscured. The tidy unity of this history is as fictive as Benton's imaginary landscape. This unity imposes a pre-modern simplicity on the origins of country music, promoting sunny stories of settlement, certainty, and universal progress over those of struggle, ambiguity, and accommodation (see Miller, 2010).

The Hall of Fame Rotunda is an important example of the techniques used by this museum to produce a naturalized frame for its curatorial choices. The museum staff takes tremendous care in demonstrating the Hall of Fame's legitimacy. The processes by which new members of the Hall of Fame are elected are described in detail in the Visitor's Companion guide book and the audio guide for this room, both of which present precisely the same information (Country Music Hall of Fame and Museum, 2004:55). More importantly, these fairly mundane aspects of selection are presented in tandem with a detailed explanation of the iconography of the rotunda, cementing the relationship between the curatorial smoothing of the complexities of social history and the rhetorical and material approximation of that history in the Hall of Fame Rotunda.

As the narrative of the Grand Rotunda suggests, popular music museums have borrowed from the social history museum, too. They use display and exhibition strategies as well as organizational schemas based on a presumed chronology in order to evoke a larger 
thematic purpose. Such exhibitions focus far less on the unique or singular object, work of art, or musical composition, and far more on the mundane, everyday object. These kinds of museums construct many of their displays from anonymous objects of largely equivalent value and status, which are meant to be collectively representative of a whole social world (Henning, 2006:27). As representative rather than unique objects (or music) for exhibition (or playing), they facilitate and foreground the construction of a larger historical narrative without getting in the way too much. As Timothy Mitchell argues, in the 'exhibitionary complex,' what 'reduced the world to a system of objects was the way their careful organization enabled them to evoke some larger meaning, such as History or Empire or Progress' (Mitchell, 2004:447). As with the distinctly national myths on display in Nashville, the displays in popular museums that are taken from history museums place the spectator inside a presumed social world and narrative, narrowing the field of vision significantly and organizing the experience of history along a carefully laid track, or what Alison Griffiths calls a 'preferred itinerary' (Griffiths, 2002:11). This materialization of national myths is a defining feature of a much wider and more historically grounded complex of representational systems, such as international exhibitions and world's fairs as well as numerous species of historical and theatrical panorama. In those cases, the spectator's experience is produced through a visual, auditory, and material rhetoric defined by what one designer of international exhibitions described as 'a combination of beauty and bombast' (Masey and Morgan, 2008: 110). Across several different kinds of display, this combination 'solicited viewers ideologically,' asking them to perform their role as participants and willing receptacles for a story that appears in many respects to be self-evident (Oleksijczuk, 2001:4-5; see also Wallis, 1994). Many popular music museums engage precisely the same strategies.

The first two rooms of the permanent exhibit at the Memphis Rock ' $n$ ' Soul Museum provide good examples. This Smithsonian Affiliate is marked by a high quality main exhibition which reflects many of the priorities of social history displays found at such museums as the Smithsonian's National Museum of American History in Washington, D.C. Moreover, in tandem with its narrative of social history, the Rock ' $n$ ' Soul Museum constructs a collective regionalist hagiography that appears as a framing gesture for the museum as a whole. Of its musical subjects it claims the following:

Their groundshaking contributions led a harmonious civil rights movement which integrated the music industry, inspired many of the world's leading musicians through today, influenced almost every known musical genre, and changed the cultural complexion of the world forever. ${ }^{3}$

This is the lens through which we can gain a profitable understanding of these two rooms which explain the social, economic, and cultural origins of the rock and soul music that was produced in Memphis between about 1945 and 1965. The galleries do so by presenting us with an originating mythos that is clearly meant to be largely fixed and uncontestable.

Entry into these rooms is preceded by an orientation video which provides an extended iteration of the familiar narratives of early twentieth-century Memphis and the broader American south: economic hardship spurred a mass migration and urbanization across the region that was followed inevitably by the production of new forms of culture and music. The narrator comments:

During the 1950s and 60s, Memphis was at the crossroads of a profound musical exchange as rhythm and blues, rock and roll soul music exploded from the city reshaping the nation's music and culture. The story begins in the countryside around Memphis where farmers and sharecroppers expressed the rhythms of their daily lives in country, blues, and gospel music. From these poor people emerged a rich musical heritage (Memphis Rock ' $n$ ' Soul Museum.).

The ebbs and flows of modernity and the unique circumstances of this region produced the social tensions and collaborations necessary to inspire the music that followed:

So they came to Memphis by the hundreds, by the thousands, from sweltering cotton fields, rugged hills, small towns, and endless lowlands. They brought their hope for a better life and they brought their music, country, folk, jazz, and blues. 
It permeated the streets of Memphis and filled the air with possibilities (Memphis Rock 'n' Soul Museum.).

This is just one of the more familiar stories plucked from a heavy and crowded field of narratives about this place and this region in the middle decades of the twentieth century, stories spread across multiple genres of academic and popular history writing (see Dickerson, 1996; Lauterbach, 2015).

The first two rooms of the exhibition make this story material through the use of an array of largely anonymous, everyday objects set before us and images set on the walls behind them. This combination creates scene or setting for spectators. On the left as they enter the first room is a sharecropping scene. Taking up most of the wall are two images. One is a black and white image of a white man in a hat and tie measuring a bag of cotton as an African-American sharecropper looks on. In front, on the floor before us is a small bale of cotton and next to it hangs a bag similar to the one being weighed in the image. The next image is a larger black and white panoramic shot of a cotton field with an older African-American and a young African-American boy working with hoes in the foreground. Behind them is a team of two mules tethered to a plow being led by another worker. Before viewers in the exhibit room is a plow of the type in the photograph, this one tethered to a wire frame in the shape of a mule. Occupying the rear wall just to the right of this display is a model of the front porch of a small wooden cabin, complete with an overhanging roof, weathered wooden support beams, a brick chimney, and window. Against the wall stands a life-sized portrait of an African-American man posing with two African-American boys. Each of the boys holds a small guitar. Again, the image is twinned with the everyday objects in front of it, in this case, a barrel, a wooden chair, as well as several parts of a plow harness hanging on the front wall of the cabin.

The second room consists of three scenes, all presented in a similar way. One is meant to evoke a typical scene inside a white farmer's home. On a weathered wooden floor sits a small stove, wooden chair, and wooden kitchen table placed in front of several life-sized images on the walls behind them. One is a floor-to-ceiling image of the wall of a family home with a portrait of a family patriarch and a guitar hanging on the wall. The other pictures are of family members, including a father standing with his two sons and another young boy sitting behind the table reading the newspaper. On the table are strewn various archaic cooking implements as well as empty Dr. Pepper bottles and a battery-operated radio. The radio is particularly telling because it allows the curators to tell us that many homes such as this did not have electricity until the 1930s or 40s. The second scene depicts a horse-drawn cart piled high with a white family's modest belongings, including bedding and wooden chair placed on top. Behind the cart is another life-sized photo of a very similar conveyance with its accompanying family approaching a sign telling spectators that they are on their way to Memphis. The final scene is of a small single metal-frame bed with two dresses and children's bedclothes laid out on top. Around the bed are a wash pan on a bedside table and a bucket on the floor. The same wooden flooring as appears across the room in the kitchen display. However, this is not meant to be the same home. The images on the wall near this bed are of an African-American family, one featuring a child operating the crank handle on a small phonograph. Musical instruments are scattered throughout this room and the previous one, including a dulcimer and fiddle, as well as record players, records, and several radios. In addition to explaining the broad economic circumstances of the population whose lives are referenced in these displays, the audio guide also features playlists of songs, one from white performers such as Roy Acuff, Jimmy Rogers, and the Carter Family, and a second list of African American performers such as Big Bill Broonzy, Furry Lewis, and Sleepy John Estes.

These two rooms suggest that all poor southerners, African American and white alike, were subjected to more or less the same economic and social forces and to some extent all experienced a common daily struggle. The scenes that face each other across these two rooms bear more than a passing resemblance to the tradition of ethnographic life displays (see Griffiths, 2002). They are populated with objects whose equivalence in status and value is as plain as their anonymity. Their arrangement and presentation also suggests that their owners mostly responded to their hardships in the same way. Music is posited here almost exclusively as a pervasive form of social consolation and emotional salve. It appears 
almost entirely separated from the larger spheres of racial and sexual politics long present in places such as Memphis, especially a Memphis on the cusp of a peculiarly American form of modernity. Little mention is made of the particulars of struggle faced by these distinct and segregated communities, with African Americans in particular facing a rampant and resurgent white supremacy in the late nineteenth and early twentieth centuries that was the direct cause of tremendous violence and several subsequent waves of migration (see Brundage, 1997; MacLean, 1994). The displays in these rooms carefully and subtly evoke social and racial regimes of this region while gesturing at the agency of those trying to overcome oppression. The objects call up connections with the past that go beyond the immediate, but they do so in such a way as to obscure their profound differences.

In contrast to exhibitions that present items as generic or anonymous, some popular music museums allow visitors to engage with the past by displaying highly specific objects in all their uniqueness and particularity. It has become a cliché of museum scholarship that the modern museum has its origins in the cabinets of curiosity or wonder that emerged in Europe in the 1500s (see Abt, 2006:119). Not only were such collections 'a necessary accompaniment to great wealth' (Henning, 2006:21), but they were enmeshed in networks of wealth, power, and knowledge of which they act as material evidence. These collections were not simply wondrous or encyclopedic, they were also instructional, and the instruction went far beyond mere aesthetic appreciation of their contents (see also MacGregor, 2007; Davenne and Fleurent, 2012). Popular music museums display wondrous objects as well, objects that are so specific that the museum displaying them may explicitly attempt to produce a kind of aura around them. The range of such objects is fairly broad, from the sublime, such as the white piano John Lennon played in the video for 'Imagine,' to the practical, such as Wanda Jackson's acoustic guitar, to the curious, such as the letter a young Johnny Cash received from his member of Congress in response to inquiries into the possibility of finding work at the National Security Agency or the Federal Communications Commission.

The links between the collections of contemporary popular music museums and the history of museum accessions appear very clearly at the Experience Music Project in Seattle, where there is a demonstrative and instructional room. Called the 'Guitar Gallery: The Quest for Volume,' the stated purpose of the gallery is to show how 'the electric guitar, like the automobile, became a symbol of American ingenuity and design. ${ }^{4}$ Its wider purpose is to incorporate the music produced by a wide range of often marginalized people into the familiar and triumphant space of American exceptionalism. At any one time, the museum will display about fifty-five guitars from its larger collection. On my visit, the gallery included a few highlighted items, such as one of four square 'Bo Diddley's guitars and Kurt Cobain's light blue Fender Mustang. It also included a Spanish guitar from the 1800s with stunning wood and pearl inlay and decorative flourishes, as well as a 1920s Stroh Hawaiian guitar, an ungainly looking device with a small round metal body with an acoustic amplification horn coming off the back.

The guitars were arranged chronologically, with notes regarding the innovations, struggles, and inventions that took musicians from quiet 'parlor guitars' to the resonant metal bodies of the National guitar to the 'modern god of distortion,' the solid-body Fenders that created a new and distinct standard for this instrument's sound (Experience Music Project, n.d.). As an 'accompaniment' to the 'great wealth' of the amateur scholar, collector, patron, and museum founder, Microsoft co-founder Paul Allen, the Guitar Gallery is a consummate effort. It demonstrates Allen's not only power and taste, but also his knowledge and his 'cool' credentials. Allen is, after all, the owner of 'the white Fender Stratocaster that Hendrix played at the 1969 Woodstock festival' (Fricke, 2000:41). The display of these 'vintage, world-changing guitars' (Experience Music Project, n.d.) is not simply an educational exercise, but like the rest of the museum, it is an exercise in the creation perceptions of a particular kind of value. The Guitar Gallery suggests that its objects and the new sounds they produced were used by people all of whom were seeking some form of transcendent form of musical expression. Each item is a perfectly maintained, glossy reflection of a particular set of standards for artistry and skill, values considered by their advocates to be universal. As one observer argued, at the EMP it 'seemed to be a given that a music that sells rebellion and disenfranchisement is now shared as a common language between the most troubled youth and the most powerful 
elite' (Strauss, 2000:4).

The Guitar Gallery suggests a relationship that is part of a much more widespread and very particular complex of museum experience, which establishes a relationship between mundane objects and what we might call famous ones. ${ }^{5}$ Within this relationship, the range of objects we experience in popular music museums range from being mere curios to becoming material anchors within reconstructed historical scenes and trajectories to becoming objects of pilgrimage within reconstructed or preserved sites. That is to say, each is the real thing, the actual guitar, the very shoes, the exact mixing desk, that adds a particular form of social weight to a confected scene or imagined space of historical experience. These scenes run the gamut from the fanciful to the earnest, from the substantive to the poignantly small and fleeting. What they have in common is the production of the experience of a certain intimacy, contact, or connection with a broader social formation constructed by the displays: the presumed collective musical past upon which their appeal to their public depends.

This construction of a common past links the historical presences built into special places such composers' houses, artists' museums, shrines, or pilgrimage sites with the displays one finds at a wax museum or in the ethnographic group life display common to natural history museums. Special places tend to play on the authenticity of the site the display inhabits. We touch the past simply through our presence there. The latter, wax museums or ethnographic exhibits, reconstruct that past in a thoroughly confected, but nevertheless extremely exacting manner. All of these attractions offer a subtle and dynamic relationship between a provision of a certain kind of proximity and intimacy with the past and an overarching didactic provision of carefully-curated knowledge about that past (see Griffiths, 2002; Kourdounaris, 2013; Sandberg, 2003). They do so by providing an artfully crafted pretense to an immediate, material, and sensory engagement with events and places that have disappeared, or in some cases never actually existed. As Sandberg argues, in these kinds of displays 'the material world so carefully preserved has always in some important sense already expired' (Sandberg, 2003:10). Therefore, in popular music museums such displays and accompanying recordings are meant to offer access to those experiences that are not expired, most notably the connections among visitors produced through shared memories. These museums seek to use these preexisting social relationships to form a coherent social entity, or a kind of ideal demos. As with various kinds of museums and displays that began appearing in the late nineteenth century, contemporary popular music museums also share 'a fascination with the authentic corporeal trace, with elaborate systems of effigy, and the spectator's relationship to themed space' (Sandberg, 2003:14).

We can see this fascination throughout the exhibits at the Beatles' Story in Liverpool, exhibits that are defined by a similar attention to origins and the construction of a musical subject that is presumed to be one node in a larger preexisting set of social connections which the museum claims merely to be activating. The efficacy of the Beatles' Story as a whole turns on the way the institution's extensive collection of photographs, important objects, and reconstructed scenes recalls those origins. Thus a fairly standard biographical narrative is anchored by unique objects, such as John Lennon's hip flask and an original Sgt. Pepper suit, as well as by reconstructed settings. At the entry, we are initiated into the Beatles' story with the fateful meeting of John and Paul at the Woolton Church Fete. We are then asked to follow the narrative through to Lennon's death, the moment after which no rumored Beatles reunion was possible. Many objects punctuate this tale with a weight not available to sounds and imagery alone. Early on, for example, we are shown an oddly pristine guitar, but not just any guitar. It is the same type of guitar being played by the eerily familiar-looking child in the large family photo hanging on the wall behind the display case. Remarkably, this exact model of guitar was found in the house at 251 Menlove Avenue in Liverpool in the late 1960s. Some fans will know right away that this was John Lennon's childhood home. The museum then takes up the story in an accompanying panel. Ernest Burkey, the owner of the house since the late 1960 s, explained,

builders had been carrying out some recent work in the loft and had discovered a few items hidden up there gathering dust. A Dallas Tuxedo guitar dating back to the late 1950's and two banjo magazines dated 1939 and 1941. Although the 
banjo magazines almost certainly belonged to John's mother, Julia, no definite link between John and the guitar has yet been uncovered. This does not rule out the possibility though... was this John Lennon's guitar? [Emphasis in the original.]

As visitors work their way through further through the exhibits, they pass through the expected array of items and images, such as a map marked with important Beatles-related sites, photos of a bombed out Liverpool City Centre taken not long after World War II, and pictures of the very youthful Lennon and McCartney playing in The Quarrymen. As they move through the section of the exhibit about Hamburg, however, something strange appears. Just off to the side of a small mockup of the entrance to the Star Club, complete with a sign reading 'Auf Verkauft' posted in front of a large image of the Beatles performing, there is a life-sized image of John Lennon leaning in a doorway. About a foot away stands a wax model of a woman with a black vinyl raincoat, a sparkly red scarf around her neck above her low cut black dress, and bright red make up on her immobile, shiny cheeks. She is clearly a model of a prostitute, her presence meant to indicate the sleazy end of town in which the Beatles plied their early trade. The wax figure is provocative not simply because it meant to be a sex worker, but because as a display method, it seems out of place in a reasonably contemporary museum. Then, in another room spectators encounter a mockup of the offices of Mersey Beat, a music magazine started by a school friend of Lennon's in the early 1960s. On the audio guide, one of the original editors tells us with a sly laugh how the magazine made the Beatles famous. The room is incredibly detailed with a Mersey Beat front page announcing 'Beatles Top Poll' along with a poster for a show at The Royal Iris. A series of clippings are strung from one wall to the other over desks fully kitted out with vintage phones and typewriters. And there he is, one of the editors, fully realized in wax, sitting at his desk taking his cup of tea while talking on the phone. Finally, after visitors walk through a good-sized mockup of the Cavern Club and the singles wall at NEMS, the family business in which future band manager Brian Epstein worked, they come across what has to be regarded as one of the main mockups in the museum, the Beatles playing in Abbey Road Studios. The scene comprises a narrow space, complete with stiff, awkwardlooking wax Beatles all wearing matching black vests and their familiar haircuts. The quality of the waxwork probably would not trouble the artists at Madame Tussaud's very much. The room has the requisite guitars, amps, microphones, and drums, but also several guitar cases notched along the front wall, a deft, subtle hint of verisimilitude in an otherwise unconvincing display. 'Love Me Do' plays on a constant loop outside.

The somewhat amateurish quality of these wax figures and their lack of resemblance to their subjects reveal their complex purposes and meanings. These particular forms cannot even remotely produce what Sandberg calls the 'uncanny qualities of presence and absence' or 'the exploration of threshold space' that early wax figures were expected to provide (Sandberg, p. 19). Instead, these particularly bad wax figures evoke a slightly sad two-pronged nostalgia, one prong for the subjects of these displays, the young, effervescent Beatles who provided such a contrast to the dour postwar Britain shown at the start of their exhibition. The second prong provides the slightest acknowledgment that certain of these ways of remembering the musicians are obsolete as well. In this particular case, the figures can only dimly recall the effect that wax figures are meant to create. Obviously this is not intentional, but neither can it be entirely unwanted. Otherwise these figures, which are by no means central to the museum as a whole, could simply be removed and replaced with other kinds of recording media found almost everywhere else in the museum. ${ }^{6}$

\section{Conclusion}

Throughout these museums, audiences can see a characteristic type of musical experience. They are routinely placed in a very particular position of communal belonging. By asking visitors to recall some piece of a common past or experience either through mundane objects, famous ones, or the particularities of the institutions themselves, curators invite them to inhabit a form of intimacy and familiarity which, while routinely presumed to reside elsewhere, has in fact been produced by the institutions themselves. It has been produced through a reliance on a wide range of exhibitionary styles and types drawn from a rich array of institutions. 
As noted at the start of this article, the existing literature on the popular music museum is somewhat limited. Given the remarkable expansion of the museum sector worldwide in recent decades, an expansion which has produced an increasing number of major museums dedicated exclusively to popular music, it is an opportune time to revisit and expand the body of literature. What I have sought to do here is to highlight the broad the range of exhibitionary types commonly used in high-profile popular music museums. The use of many different forms of museum display drawn from what I have called the populist-vernacular stream of museum display and the institutional-educational stream show us the distinct characteristics of these institutions. I have argued that there are strong, if unacknowledged, links between exhibitionary forms common to popular music museums drawn from sources such as art museums, social history museums, the ethnographic life display, as well as wax museums. Clearly, these museums use these forms of visual, aural, and material display to establish themselves as influential intermediaries in the communication of specific sets of values and priorities in the public life of popular music. They do so by trying to render the common and popular experience of popular music in fixed displays that appear to express a common stock of these ideas and values, but also definitively shape them. However, they often do so in ways that obscure the complexity and contradictions of a history that is anything but settled, despite what these displays might sometimes imply. In particular, these displays often flatten conflict or present versions of social history that are far more harmonious than they in fact were. Thus, in one critical way the museums fall far short of their subjects, given how popular music and the musicians that created it often succeeded in capturing or reflecting a wide variety of human experience, familiar and unfamiliar, inclusive and exclusive.

Received: 1 July 2016

Finally accepted: 20 February 2017

\section{Notes}

1 The original hymn on which the Carter family version is based is called 'Will the Circle $\mathrm{Be}$ Unbroken?'

2 Adams, Henry. (n.d.) Thomas Hart Benton: The Sources of Country Music. Country Music Hall of Fame and Museum. http://countrymusichalloffame.org/ ContentPages/thomas-hart-benton1. Accessed on 3 April 2016.

3 Memphis Rock 'n' Soul Museum. (n.d.) Our Galleries. http://www.memphisrocknsoul.org/ galleries. Accessed on May 30, 2016. A version of this claim also appears on a widely distributed handbill advertisement for the museum.

4 Experience Music Project (n.d.) Guitar Gallery: The Quest for Volume. http://www. empmuseum.org/at-the-museum/museum-features/guitar-gallery-the-quest-for-volume. aspx. Accessed May 30, 2016.

5 Baker et. al. (2016b) offer a brief but interesting passage on this issue at the Guitar Gallery, offering a curatorial perspective.

6 I am using the term 'recording media' here the way Sandberg (2003) does, that is as an attempt at stilling or freezing something at a particular moment in its history.

\section{References}

Abt, Jeffery. (2006) 'The Origins of the Public Museum' in S. Macdonald, A Companion to Museum Studies, 115-134, Malden, Ma.: Blackwell.

Baker, S., L. Istvandity, and R. Nowak (2016a) 'The Sound of Music Heritage: Curating Popular Music in Music Museums and Exhibitions' International Journal of Heritage 
Studies, 22 (1), 70-81.

(2016b) 'Curating Popular Music Heritage: Storytelling and Narrative Engagement in Popular Music Museums and Exhibitions' Museum Management and Curatorship, 31 (4), 369-385.

Bennett, Andy. (2009) “'Heritage Rock”: Rock Music, Representation and Heritage Discourse' Poetics, 37 479-489.

Bennett, A., and I. Rogers. (2016) 'Popular Music and Materiality: Memorabilia and Memory Traces.' Popular Music and Society, 39 (1) 28-42.

Bennett, Tony, (1995) The Birth of the Museum: History, Theory, Politics. New York: Routledge.

(2006) 'Civic Seeing: The Museum and the Organization of Vision' in S. Macdonald, $A$ Companion to Museum Studies, 263-281, Malden, Ma.: Blackwell.

Bergengren, Charles. (1999) 'Simply Contradictory: The Rock and Roll Hall of Fame and Museum' Journal of American Folklore, 112 544-550.

Brabazon, T., and S. Mallinder. (2006) 'Popping the Museum: The Cases of Sheffield and Preston.' Museum and Society, 4 (2) 96-112.

Brandellero, A., and S. Janssen (2014) 'Popular Music as Cultural Heritage: Scoping Out the Field of Practice.' International Journal of Heritage Studies, 20 (3) 224-240.

Brundage, W. Fitzhugh, (ed.) (1997) Under Sentence of Death: Lynching in the South. Chapel Hill, N.C.: University of North Carolina Press.

Cohen, Sara, et. al. (eds.) (2015) Sites of Popular Music Heritage: Memories, Histories, Places. New York: Routledge.

Cohen, Sara, (2007) Decline, Renewal and the City in Popular Music Culture: Beyond the Beatles, Aldershot, UK: Ashgate.

Colligan, Mimi, (2002) Canvas Documentaries: Panoramic Entertainments in NineteenthCentury Australia and New Zealand, Melbourne, Vic.: Melbourne University Press.

Country Music Hall of Fame and Museum (2004) A Visitor's Companion, Nashville, Tn.: Country Music Foundation.

Crary, Jonathan. (2002) 'Géricault, the Panorama, and Sites of Reality in the Early Nineteenth Century,' Grey Room 9, 5-25.

Davenne, Christine, (2012) Cabinets of Wonder, New York: Abrams.

Dickerson, James, (1996) Goin' Back to Memphis: A Century of Blues, Rock 'n' Roll, and Glorious Soul. New York: Schirmer Books.

Forman, Murray, (2002) ‘No Sleep ‘Til Brooklyn' American Quarterly, 54 (1) 101-127.

Fricke, David, (2000) 'The \$240 Million Temple of Rock: Paul Allen's Experience Music Project Opens in Seattle' Rolling Stone (Jul 6, 2000-Jul 20, 2000): 41, 48.

Gibson, C., and J. Connell, (2007) 'Music, Tourism and the Transformation of Memphis' Tourism Geographies, 9 (2) 160-190.

Greenhalgh, Paul, (1989) ‘Education, Entertainment and Politics: Lessons from the Great 
International Exhibitions' in P. Vergo (ed.), The New Museology, 74-98, London: Reaktion Books.

Griffiths, Alison, (2002) Wondrous Difference: Cinema, Anthropology and Turn-of-theCentury Visual Culture, New York: Columbia University Press.

Henning, Michelle, (2006) Museums, Media and Cultural Theory, Maidenhead, UK: Open University Press.

Kalata, J., Z. Doering, and A. Pekarik, (1997) 'On the Road With Rock and Soul' Curator: The Museum Journal, 40 (4) 259-278.

Kirshenblatt-Gimblett, Barbara, (2006) 'Exhibitionary Complexes' in Karp, I. et. al. (eds.), Museums Frictions: Public Cultures/Transformations, 35-45, Durham, N.C.: Duke University Press.

Koudounaris, Paul, (2013) Heavenly Bodies: Cult Treasures and Spectacular Saints from the Catacombs, New York: Thames and Hudson.

Lauterbach, Preston, (2015) Beale Street Dynasty: Sex, Song, and the Struggle for the Soul of Memphis, New York, New York: W. W. Norton \& Company.

Leonard, Marion, (2010) 'Exhibiting Popular Music: Museum Audiences, Inclusion and Social History' Journal of New Music Research, 39 (2) 171-181.

(2007) 'Constructing Histories Through Material Culture: Popular Music, Museums and Collecting' Popular Music History, 2 (2) 147-167.

MacGregor, Arthur, (2007) Curiosity and Enlightenment: Collectors and Collections from the Sixteenth to the Nineteenth Century, New Haven, Ct.: Yale University Press.

MacLean, Nancy, (1994) Behind the Mask of Chivalry: The Making of the Second Ku Klux Klan New York: Oxford University Press.

Masey, J., and C. Morgan, (2008) Cold War Confrontations: US Exhibitions and Their Role in the Cultural Cold War, Baden, Switzerland: Lars Müller Publishers.

Memphis Rock 'n' Soul Museum. (n.d.) Rock 'n' Soul: Social Crossroads. Orientation Film.

Message, Kylie (2006) 'The New Museum' Theory Culture and Society: Explorations in Critical Social Science, 23 (2-3) 603-606.

Miller, Karl, (2010) Segregating Sound: Inventing Folk and Pop Music in the Age of Jim Crow, Durham, N.C.: Duke University Press.

Mitchell, Timothy, (2004) 'Orientalism and the Exhibitionary Order' in Preziosi, D., and C. Farago (eds.), Grasping the World: The Idea of the Museum, 442-460, Aldershot, UK: Ashgate.

Mortensen, C., and J. Westergaard Madsen (2015) 'The Sound of Yesteryear on Display: A Rethinking of Nostalgia as a Strategy for Exhibiting Pop/Rock Heritage,' International Journal of Heritage Studies, 21 (3) 250-263.

Moore, Kevin, (1997) Museums and Popular Culture, London: Cassell.

Moore, Kathleen, (1995) 'Exhibition Review: The Motown Sound: The Music and the Story,' Curator: The Museum Journal, 38 (4) 274-280. 
Oleksijczuk, Denise, (2011) The First Panoramas: Visions of British Imperialism, Minneapolis: University of Minnesota Press.

Preziosi, D., and C. Farago (eds.) (2004) Grasping the World: The Idea of the Museum Aldershot, UK: Ashgate.

Reising, Russell (2001) 'The Secret Lives of Objects: The Secret Stories of Rock and Roll: Cleveland's Rock and Roll Hall of Fame and Museum and Seattle's Experience Music Project,' American Quarterly, 53 (3) 489-510.

Roberts, L., and S. Cohen (2014) 'Unauthorising Popular Music Heritage: Outline of a Critical Framework,' International Journal of Heritage Studies, 20 (3) 241-261.

Rydell, Robert, (2006) 'World's Fairs and Museums,' in S. Macdonald, A Companion to Museum Studies, 135-151, Malden, Ma.: Blackwell.

Sandberg, Mark, (2003) Living Pictures, Missing Persons: Mannequins, Museums, and Modernity, Princeton, N.J.: Princeton University Press.

Strauss, Neil, (2000) 'Making a Museum Out of Music, Part 2,' New York Times, E1+, June 26.

Suisman, David, (2000) 'Review: "This Land Is Your Land": The Life and Legacy of Woody Guthrie' Journal of American History, 87 (3) 973-977.

Wallis, Brian, (1994) 'Selling Nations: International Exhibitions and Cultural Diplomacy,' in Sherman, D., and I. Rogoff, Museum/Culture: Histories, Discourses, Spectacles, 265-281, Minneapolis, Mn.: University of Minnesota Press.

${ }^{*}$ Charles Fairchild is an Associate Professor of Popular Music at the University of Sydney and the author of Danger Mouse's The Grey Album (Bloomsbury, 2014), Music, Radio and the Public Sphere (Palgrave, 2012) and Pop Idols and Pirates (Ashgate, 2008).

*Dr Charles Fairchild, Associate Professor of Popular Music

Arts Music Unit, Seymour Centre, $4^{\text {th }}$ Floor

Sydney Conservatorium of Music

University of Sydney

Sydney NSW 2006

+61290365224

charles.fairchild@sydney.edu.au

http://sydney.academia.edu/CharlesFairchild 